\title{
Elevated expression of NEDD9 is associated with metastatic activity in gastric cancer
}

\author{
This article was published in the following Dove Press journal: \\ OncoTargets and Therapy \\ 10 March 2015 \\ Number of times this article has been viewed
}

\section{Si-sen Zhang' \\ Li-hua Wu' \\ Qing Liu' \\ Kui-sheng Chen ${ }^{2}$ \\ Xie-fu Zhang ${ }^{3}$}

'The Emergency Department, People's Hospital of Zhengzhou, Zhengzhou, Henan, People's Republic of China; ${ }^{2}$ Department of Pathology, ${ }^{3}$ General Surgery Department, The First Affiliated Hospital of Zhengzhou University, Zhengzhou, Henan, People's Republic of China
Correspondence: Si-sen Zhang The Emergency Department, People's Hospital of Zhengzhou, Zhengzhou, 450000 Henan, People's Republic of China Email zsszzrmyy@।63.com
Objective: To investigate the protein and mRNA expression of NEDD9 in gastric cancer (GC) tissues, adjacent atypical hyperplasia tissues, and normal gastric mucosa tissues, and analyze its relationship with the pathological features and prognosis of GC.

Methods: Forty cases of GC tissues, 20 cases of adjacent atypical hyperplasia tissues, and 40 cases of normal gastric mucous tissues were collected. Immunohistochemistry and Western blot were used to examine the expression of NEDD9 protein in various tissues. Situ hybridization and reverse transcription polymerase chain reaction were applied to detect the expression of NEDD9 mRNA in various tissues. The correlation of NEDD9 expression with invasion and metastasis of GC was analyzed.

Results: The protein expression level of NEDD9 was significantly higher in GC tissues than in adjacent atypical hyperplasia tissues and normal gastric mucous tissues $(P<0.05)$. The protein expression level of NEDD9 was positively related to the invasion depth of carcinoma and tumor lymph node metastasis $(P<0.05)$, but unrelated to age, sex, tumor size, and clinical classification of cancer $(P>0.05)$. The mRNA expression level of $N E D D 9$ was also significantly higher in GC tissues than in adjacent atypical hyperplasia tissues and normal gastric mucous tissues $(P<0.05)$, and positively related with the tumor lymph node metastasis and invasion depth of carcinoma $(P<0.05)$.

Conclusion: NEDD9 is involved in the occurrence and development of GC, and it may be an important biological marker of GC metastasis and infiltration.

Keywords: immunohistochemistry (IHC), invasion, metastasis

\section{Introduction}

Gastric cancer (GC) is one of the most common gastrointestinal cancers worldwide, with the characteristics of high incidence, concealed onset, high risk of metastasis, and high mortality. The geographic distribution of incidence and mortality of GC varies remarkably worldwide, with the mortality rate in the People's Republic of China accounting for $42 \%$ of the whole world. ${ }^{1-3}$ Several agents targeting specific molecules have been investigated for the treatment of GC in many preclinical and clinical studies. During the past few decades, the mortality of GC has declined, mainly due to its early detection by endoscopic techniques, surgical techniques, and advances in chemotherapy. ${ }^{4-6}$ However, the prognosis of patients diagnosed with GC continues to be dismal, despite improving surgical and adjuvant treatment approaches, with 5-year overall survival less than $25 \%{ }^{7}$ The main causes for treatment failure and death among GC patients are tumor invasion and metastasis. ${ }^{8}$ The occurrence and development of GC is a complex, multistage process involving multiple genetic and epigenetic alterations of oncogenes, tumor growth factors, tumor suppressor genes, genetic stability, cell cycle regulators, and signaling molecules. ${ }^{9}$ Thus, identification of novel 
diagnostic and prognostic tumor biomarkers for GC diagnosis and novel therapeutic targets for treatment have become the focus in this field.

Proteins of the Crk-associated substrate (CAS) family (BCAR1, ${ }^{10} \mathrm{NEDD} 9,{ }^{11} \mathrm{EFS} / \mathrm{SIN},{ }^{12} \mathrm{CASS} 4 / \mathrm{HEPL}^{13}$ ) are integral players in normal and pathological cell biology. A growing number of studies have found that increased expression of Cas proteins contributes to human tumor aggressiveness. CAS proteins act as scaffolds to regulate protein complexes controlling migration and chemotaxis, cell cycle, differentiation, apoptosis, and progenitor cell function. ${ }^{14}$ Overexpression of CAS proteins has been strongly linked to poor prognosis and increased metastasis in cancer, as well as resistance to firstline chemotherapeutics in multiple types of tumor including breast cancer, lung cancer, glioblastoma, and melanoma. ${ }^{14} \mathrm{Of}$ the CAS proteins, BCAR1 and NEDD9 have been the most intensively studied. BCAR1 overexpression confers invasiveness to cultured cells, and promotes mammary tumorigenesis and lung metastasis in MMTV-HER2 and other mouse models of cancer. ${ }^{15,16}$ BCAR1 overexpression also correlates with poor prognosis in breast cancer patients. ${ }^{17,18}$ NEDD9 is an important cytoskeletal protein molecule found in 1992, and its function is associated with cell adhesion, migration and invasion, regulation of cell cycle, and apoptosis. ${ }^{19-21}$ Previous studies have indicated that elevated NEDD9 expression levels contribute to cancer metastasis in multiple cancer types, such as breast cancer, melanoma, glioblastoma, head and neck squamous cell carcinoma, lung cancer, liver cancer, and cervical cancer. ${ }^{22-30}$ Other NEDD proteins, including NEDD4 and NEDD8, have also been demonstrated to play a critical role in the development and progression of human cancers, thus they are considered as promising targets for therapeutic intervention. ${ }^{31,32}$ More recently, two studies detected the tissue expression of NEDD9 by immunohistochemistry and evaluated the prognostic significance of NEDD9 in patients with GC. Their results showed that the expression of NEDD9 was upregulated in GC, and that high expression of Nedd9 significantly correlated with cancer progression and poor prognosis in GC. ${ }^{9,33}$ These results suggest an important role of NEDD9 in the progression of GC.

In the present study, to further determine the roles of NEDD9 in the occurrence and development of GC, we detected the expression of NEDD9 protein and mRNA in 40 GC tissues, 20 cases of adjacent atypical hyperplasia tissues, and 40 cases of normal gastric mucosa by immunohistochemistry, Western blot, in situ hybridization, and RT polymerase chain reaction (RT-PCR), and explored their relationship with tumor invasion and metastasis.

\section{Materials and methods Materials}

The postoperative pathological specimens of 40 patients with GC between January 2008 and August 2010 were collected from the general surgery department of the People's Hospital of Zhengzhou, Zhengzhou, People's Republic of China, including 27 males and 13 females with the median age of 55 years (ranging from 32 to 71 years) (Table 1). All specimens were confirmed gastric adenocarcinoma through pathology.

No treatment was given before surgery. Specimens were extracted from cancer tissues with a distance of within $3 \mathrm{~cm}$ to neoplastic foci. Twenty cases of moderate-to-severe dysplasia were obtained, and 40 cases of gastroenterology endoscopy biopsy which had been diagnosed normal gastric mucosa through pathology were also collected as control.

\section{Methods}

Immunohistochemistry

An SP immunohistochemical staining kit was purchased from American ZYMED Company. NEDD9 mouse anti-human monoclonal antibodies and polyclonal rabbit anti-human NEDD9 antibodies were purchased from Santa Cruz, USA. The dyeing process was conducted according to the instructions on SP Series kits.

Uniform standards and a double-blind method were applied in the evaluation of dyeing results. All samples were evaluated and scored independently by two pathologists. A 2-point scoring method was used to determine the

Table I Clinical and pathological data of 40 patients with gastric cancer

\begin{tabular}{ll}
\hline Parameters & Number of cases \\
\hline Age (years) & 17 \\
$\quad<60$ & 23 \\
$\geq 60$ & \\
Sex & 29 \\
$\quad$ Male & 11 \\
$\quad$ Female & \\
Tumor size $(\mathrm{cm})$ & 25 \\
$<5$ & 15 \\
$\geq 5$ & \\
Extent of invasion & 18 \\
TI-2 & 22 \\
T3-4 & \\
Tumor differentiation grade & 26 \\
I-II & 14 \\
III & \\
Number of lymphatic metastasis & 17 \\
$<3$ & 23 \\
$\geq 3$ &
\end{tabular}


proportion of NEDD9 positive cells, which were classified into five grades: grade 0 , positive cells $<1 \%$; grade 1 , positive cells 2\%-25\%; grade 2 , positive cells $26 \%-50 \%$; grade 3 , positive cells $51 \%-75 \%$; and grade 4 , positive cells $>75 \%$. The extent of dyeing was also scored and classified into four grades: grade 0, no dyeing; grade 1, weak dyeing; grade 2, moderate dyeing; and grade 3, strong dyeing. The total score was calculated by multiplying the two results, then the samples were divided into four categories according to the following grades: grades $0-1$ for $(-)$; grades $2-4$ for $(+)$, grades 5-8 for $(++)$, and grades $9-12$ for $(+++){ }^{34}$

\section{Western blot}

The experimental procedure involved the following: construction of standard curve; measurement of protein concentration; extraction of total tissue protein; preparation of gel electrophoresis; electrophoresis; transmembrane and antibody incubation; and developing and fixing. X-ray film was cut into moderate size in the darkroom, then placed on the film wrapped well with plastic wrap, exposing for 3 minutes. The film was put into the developer and developing was stopped after the appearance of band, then fixed after washing, contrasted internally, and the expression of $\beta$-actin in the sample detected as the internal contrast by the same method.

\section{In situ hybridization}

The experimental procedures were as follows: the slice was dewaxed in the water with the routine method; endogenous catalase was inactivated; the membrane was permeated; mRNA nucleic acid fragments were exposed; fixed; prehybridization; cleansed after hybridization; freshly prepared 5-bromo-4-chloro-3-indolyl-phosphate/nitro blue tetrazolium substrate solution was dropped; light was avoided and color appeared; nuclear fast red staining was performed; dehydrate graded alcohol; transparent xylene; and seal neutral gum. ${ }^{35}$

For the judgment of results, 10 visions were selected under high magnification, then judgment was made according to the extent of dyeing and the percentage of positive cells (grade 0 , positive cells $<1 \%$; grade $1,2 \%-25 \%$; grade $2,26 \%-50 \%$; grade $3,51 \%-75 \%$; grade $4>75 \%$ ). The ratings for the extent of dyeing were as follows: grade 0 , no dyeing; grade 1 , weak dyeing; grade 2, moderate dyeing; grade 3, strong dyeing. The total score was calculated by multiplying the two results and the samples were divided into four categories according to the following grades: 0-1 (-); 2-4 (+); 5-8 (++); and 9-12 (+++).

\section{RT-PCR}

The experimental procedures involved the following: synthetic primer; extraction of total tissue RNA; determination of the purity and integrity; RNA integrity measurement; RT-PCR reaction; and analysis of PCR products.

For the judgment of results, DNA bands were scanned and analyzed with a Gel-Doc2000 gel imaging analysis system and the expression level of NEDD9 mRNA was determined according to the ratio between the NEDD9 density and $\beta$-actin density.

\section{Statistical methods}

SPSS version 13.0. software was used for statistical analysis. unpaired $t$-test was used to compare the means between two groups; analysis of variance was used to compare means among three or more groups. The chi-square test was used to assess differences of categorical data. Probability level less than 0.05 was used as a criterion of significance.

\section{Results}

\section{NEDD9 protein expression in tissues} Immunohistochemical detection results

NEDD9 was primarily localized in cytoplasm, and was highly expressed in GC tissue. The positive expression rate of NEDD9 in GC tissue was 92.5\% (37/40), adjacent atypical hyperplasia tissue was $40.0 \%(8 / 20)$, and normal gastric mucosa tissue was 7.5\% (3/40). The difference was statistically significant $(P<0.01)$ (Table 2$)$. The score of GC immunohistochemistry was $5.88 \pm 0.46$, which was higher than that of adjacent atypical hyperplasia tissue $(2.35 \pm 0.59)$ and normal gastric mucosa $(0.73 \pm 0.15)$ (Figure 1). $\chi^{2}$ was 58.534, $P<0.01$ (Table 2; Figures 1 and 2).

\section{The detection results of Western blot}

NEDD9 protein was highly expressed in GC tissue and the expression level in GC, adjacent atypical hyperplasia, and normal gastric mucosa tissues was, respectively, $0.863 \pm 0.029$, $0.635 \pm 0.046$, and $0.322 \pm 0.024$. The difference among the

Table 2 Expression of NEDD9 proteins in each group of tissue

\begin{tabular}{|c|c|c|c|c|c|c|}
\hline Group & Number of cases & - & + & ++ & +++ & $\chi^{2}$, P-value \\
\hline Gastric carcinoma tissue & 40 & 3 & 10 & 21 & 6 & \\
\hline Adjacent atypical hyperplasia tissue & 20 & 12 & 4 & 3 & $\mathrm{I}$ & $58.534,<0.01$ \\
\hline Normal gastric mucosa tissue & 40 & 37 & 2 & 1 & 0 & \\
\hline
\end{tabular}




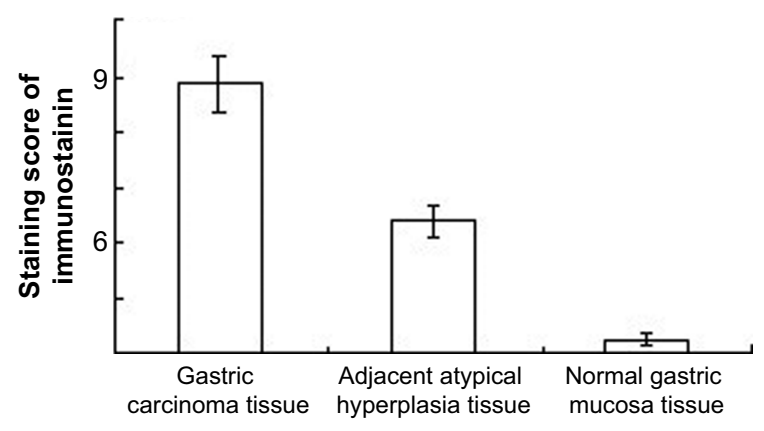

Figure I Comparison of rating on NEDD9 protein expression in each tissue type.
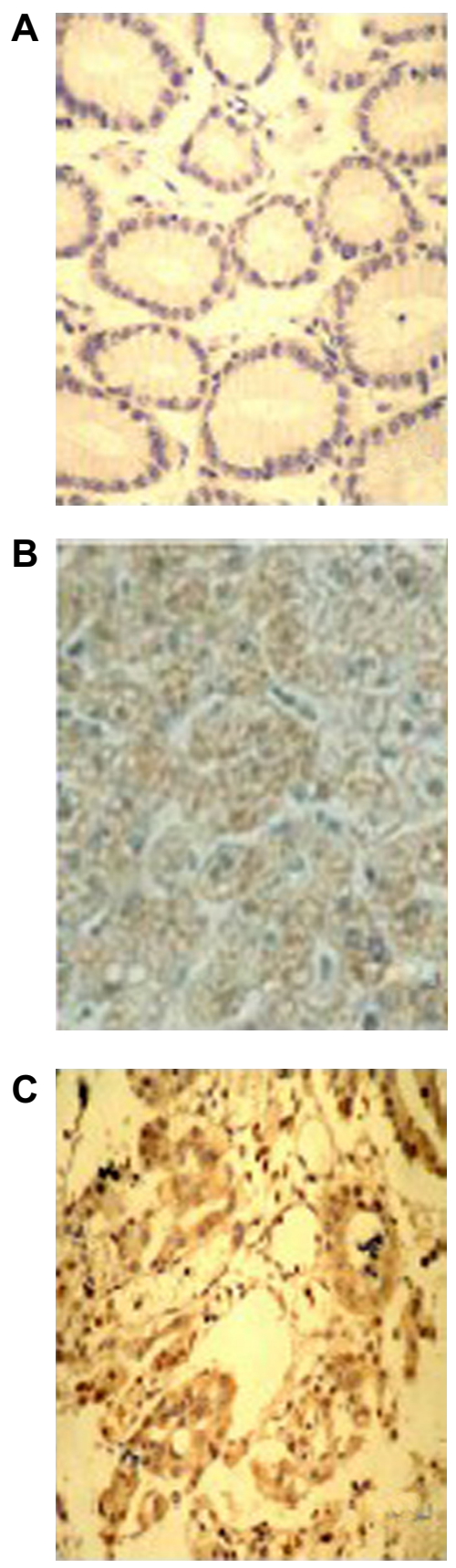

Figure 2 Comparison of NEDD9 protein expression in each tissue type $(\mathrm{SP} \times 400)$. Notes: (A) Normal gastric mucosa tissue. (B) Adjacent atypical hyperplasia tissue. (C) Gastric carcinoma tissue.
Table 3 NEDD9 protein expression in each tissue group tested by Western blot

\begin{tabular}{llll}
\hline Group & $\mathbf{n}$ & $\begin{array}{l}\text { Relative content } \\
\text { of NEDD9 protein }\end{array}$ & $\boldsymbol{F ( P )}$ \\
\hline Gastric carcinoma tissue & 40 & $0.863 \pm 0.029$ & \\
$\begin{array}{l}\text { Adjacent atypical hyperplasia } \\
\text { tissue }\end{array}$ & 20 & $0.635 \pm 0.046$ & $\mid$ |6.17। \\
Normal gastric mucosa tissue & 40 & $0.322 \pm 0.024$ & $(<0.0 \mathrm{I})$ \\
\hline
\end{tabular}

Note: Data are presented as mean \pm standard deviation.

three groups was statistically significant $(F=16.171, P<0.01)$ (Table 3; Figures 3 and 4).

The relationship between NEDD9 protein expression in gastric carcinoma tissue and clinical biology characteristics of GC

There were no significant correlations between NEDD9 protein expression level and the following indexes: sex, age, tumor size, and differentiation grade (all $P>0.05$ ), but NEDD9 protein expression was positively correlated with the depth of tumor invasion and lymph node metastasis $(P<0.05)$ (Table 4$)$.

\section{NEDD9 mRNA expression in each tissue type}

\section{Detection results of in situ hybridization}

NEDD9 mRNA was mainly localized in cytoplasm, with the positive signal of a bluish-purple color. In GC tissue, adjacent atypical hyperplasia tissue, and normal gastric mucosa tissue, NEDD9 mRNA expression decreased gradually over time. The score of NEDD9 mRNA expression in GC tissue was $5.325 \pm 0.47$, which was significantly higher than the score of adjacent atypical hyperplasia $(2.6 \pm 0.59)$ and normal gastric mucosa $(0.875 \pm 0.19)\left(\chi^{2}=36.202, P<0.01\right)$ (Table 5; Figure 5).

\section{RT-PCR detection results}

RT-PCR product detected by gel electrophoresis showed that the length of NEDD9 mRNA amplification product

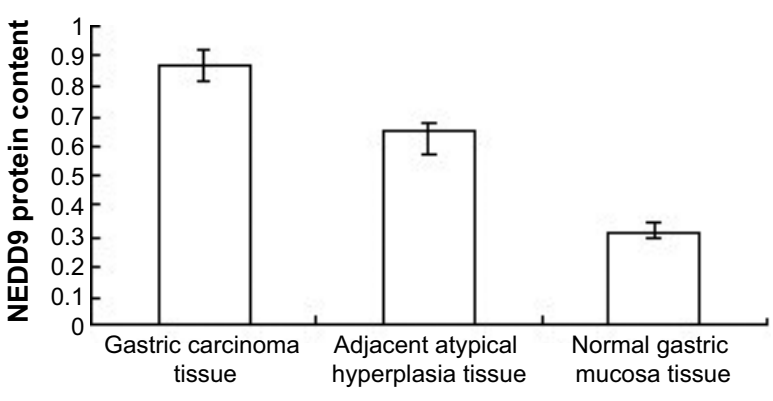

Figure 3 Comparison of NEDD9 protein expression in each tissue type. 


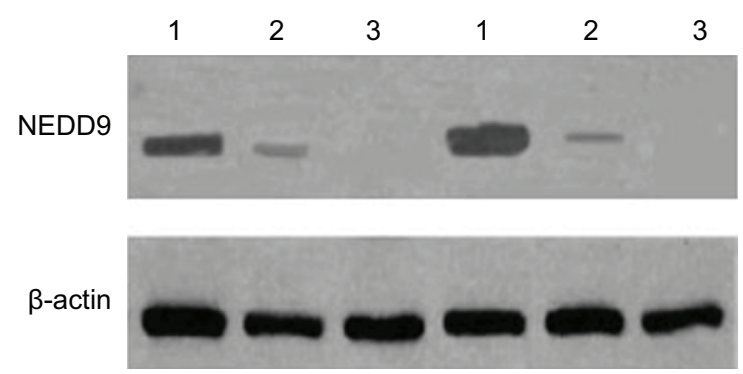

Figure 4 NEDD9 protein expression in each tissue type.

Notes: I= gastric carcinoma tissue; 2 =adjacent atypical hyperplasia tissue; $3=$ normal gastric mucosa tissue.

was $139 \mathrm{bp}$ and the length of $\beta$-actin amplification product was 268 bp. The results indicated that, in normal mucosa, NEDD9 mRNA expression was very low (positive rate $0.5 \%)$. However, the expression in GC tissue $(82.5 \%)$ and adjacent atypical hyperplasia tissue $(40.0 \%)$ was significantly higher $\left(\chi^{2}=49.102, P<0.01\right)$. The gel grayscale scanning of positive samples indicated that the expression level in GC tissue, adjacent atypical hyperplasia tissue, and normal gastric mucosa tissue was gradually decreased. Analysis of variance showed that comparison among different groups was statistically different $(F=469.461, P<0.01)$ (Tables 6 and 7; Figure 6).

Table 4 Correlation between NEDD9 protein expression in gastric carcinoma tissue and clinical biology characteristics of gastric cancer

\begin{tabular}{|c|c|c|c|c|}
\hline $\begin{array}{l}\text { Clinicopathological } \\
\text { parameters }\end{array}$ & $\mathbf{n}$ & $\begin{array}{l}\text { NEDD9 protein } \\
\text { expression level }\end{array}$ & $t$ & $P$-value \\
\hline Age (years) & & & 0.394 & 0.731 \\
\hline$<60$ & 17 & $0.754 \pm 0.11$ & & \\
\hline$\geq 60$ & 23 & $0.769 \pm 0.08$ & & \\
\hline Sex & & & 0.636 & 0.533 \\
\hline Male & 29 & $0.769 \pm 0.10$ & & \\
\hline Female & 11 & $0.738 \pm 0.11$ & & \\
\hline Tumor size $(\mathrm{cm})$ & & & 1.245 & 0.229 \\
\hline$<5$ & 25 & $0.738 \pm 0.12$ & & \\
\hline$\geq 5$ & 15 & $0.790 \pm 0.04$ & & \\
\hline Depth of invasion & & & 3.752 & $<0.001$ \\
\hline $\mathrm{TI}-2$ & 18 & $0.694 \pm 0.10$ & & \\
\hline T3-4 & 22 & $0.816 \pm 0.03$ & & \\
\hline $\begin{array}{l}\text { Tumor differentiation } \\
\text { grade }\end{array}$ & & & 0.686 & 0.501 \\
\hline I-II & 26 & $0.75 I \pm 0.10$ & & \\
\hline III & 14 & $0.78 I \pm 0.12$ & & \\
\hline $\begin{array}{l}\text { Number of lymph } \\
\text { node metastases }\end{array}$ & & & 3.498 & 0.03 \\
\hline$<3$ & 17 & $0.687 \pm 0.11$ & & \\
\hline$\geq 3$ & 23 & $0.808 \pm 0.04$ & & \\
\hline
\end{tabular}

Table 5 Comparison of NEDD9 mRNA positive rate in each tissue group

\begin{tabular}{llllllll}
\hline Group & $\begin{array}{l}\text { Number } \\
\text { of cases }\end{array}$ & - & + & ++ & +++ & $\begin{array}{l}\chi^{2}, \\
\text { P-value }\end{array}$ \\
\hline Gastric carcinoma tissue & 40 & 4 & 14 & 17 & 5 & \\
$\begin{array}{l}\text { Adjacent atypical hyperplasia } \\
\text { tissue }\end{array}$ & 20 & 10 & 5 & 5 & 0 & $\begin{array}{l}36.202, \\
<0.01\end{array}$ \\
Normal gastric mucosa tissue & 40 & 35 & 3 & 2 & 0 & \\
\hline
\end{tabular}
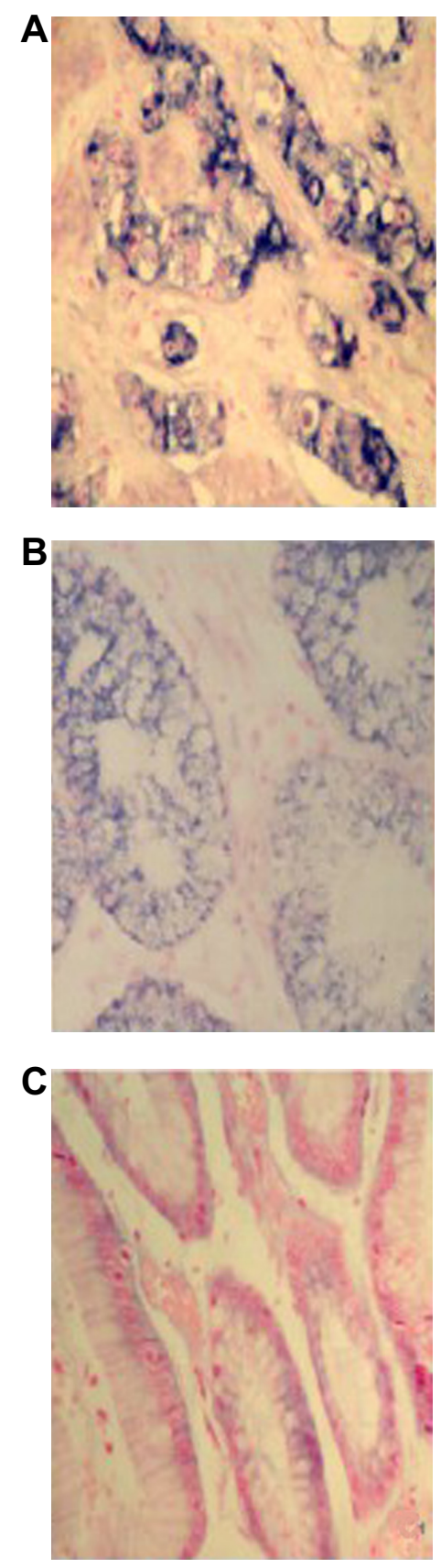

Figure 5 Comparison of NEDD9 mRNA expression in each tissue type (ISH, BCIP/ NBT, $\times 400$ ).

Notes: (A) Gastric carcinoma tissue. (B) Adjacent atypical hyperplasia tissue. (C) Normal gastric mucosa tissue.

Abbreviations: BCIP/NBT, 5-bromo-4-chloro-3-indolyl-phosphate/nitro blue tetrazolium; ISH, in situ hybridization. 
Table 6 Comparison of the positive rate of NEDD9 mRNA expression in each tissue group

\begin{tabular}{|c|c|c|c|c|c|}
\hline \multirow[t]{2}{*}{$\overline{\text { Group }}$} & \multirow[t]{2}{*}{$\mathbf{n}$} & \multicolumn{3}{|c|}{$\begin{array}{l}\text { NEDD9 mRNA } \\
\text { expression }\end{array}$} & \multirow[t]{2}{*}{$\chi^{2}(P)$} \\
\hline & & - & + & $\begin{array}{l}\text { Positive } \\
\text { rate (\%) }\end{array}$ & \\
\hline Gastric carcinoma tissue & 40 & 7 & 33 & 82.5 & \\
\hline $\begin{array}{l}\text { Adjacent atypical hyperplasia } \\
\text { tissue }\end{array}$ & 20 & 12 & 8 & 40.0 & $\begin{array}{l}49.102 \\
(<0.01)\end{array}$ \\
\hline Normal gastric mucosa tissue & 40 & 38 & 2 & 0.5 & \\
\hline
\end{tabular}

The relationship between NEDD9 expression in gastric carcinoma tissue and clinical biology characteristics of GC

NEDD9 expression was correlated with depth of tumor invasion and lymph node metastasis $(P<0.05)$. However, no significant associations of NEDD9 expression with sex, age, tumor size, and differentiation grade were found (all $P>0.05$ ) (Table 8).

\section{Discussion}

The incidence of GC is in the lead among the digestive tract cancers. In spite of many advances in diagnostic mode, chemotherapy, and radiation therapy, relatively little improvement has been achieved within the last decade in terms of prognosis and quality of life for patients with GC. Given the frequent failure of conventional treatment strategies, many cancer-related biomarkers have been characterized with the goal of finding promising therapeutic targets and developing novel anticancer therapies. In recent years, several targeted drugs or antibodies and cancer vaccines have been reported. ${ }^{36,37}$ In fact, identification of novel diagnostic and prognostic tumor markers for GC diagnosis and novel therapeutic targets for treatment are major goals in this field.

The current study showed the protein expression level of NEDD9 was significantly higher in GC tissues than in adjacent atypical hyperplasia tissues and normal gastric mucous tissues. The protein expression level of NEDD9 was positively related to the invasion depth of carcinoma

Table 7 Comparison of relative content of NEDD9 mRNA expression in each tissue group

\begin{tabular}{llll}
\hline Group & $\mathbf{n}$ & $\begin{array}{l}\text { Relative content } \\
\text { of mRNA }\end{array}$ & $\boldsymbol{F ( P )}$ \\
\hline Gastric carcinoma tissue & 40 & $0.762 \pm 0.094$ & \\
$\begin{array}{l}\text { Adjacent atypical hyperplasia } \\
\text { tissue }\end{array}$ & 20 & $0.398 \pm 0.048$ & $469.46 \mathrm{I}$ \\
Normal gastric mucosa tissue & 40 & $0.123 \pm 0.029$ & $(<0.00 \mathrm{I})$ \\
\hline
\end{tabular}

Note: Data are presented as mean \pm standard deviation.

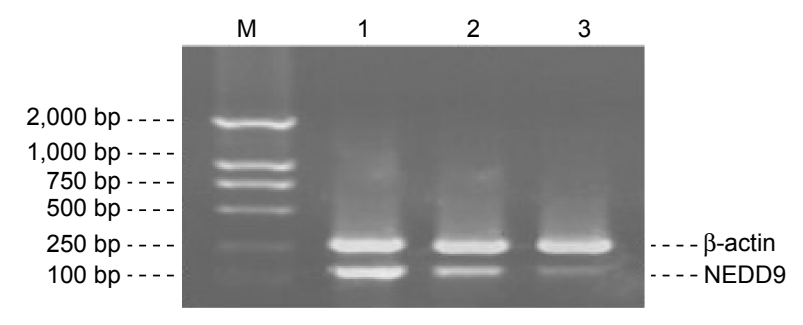

Figure 6 Comparison of NEDD 9 mRNA expression in each tissue type. Notes: I= gastric carcinoma tissue; 2 = adjacent atypical hyperplasia tissue; $3=$ normal gastric mucosa tissue.

Abbreviation: M, marker.

and tumor lymph node metastasis, but unrelated to age, sex, tumor size, and clinical classification of cancer. The mRNA expression level of $N E D D 9$ was also significantly higher in in GC tissues than in adjacent atypical hyperplasia tissues and normal gastric mucous tissues, and positively related with the tumor lymph node metastasis and invasion depth of carcinoma. Our results indicate that NEDD9 is involved in the growth and development of GC, and it may be an important biological marker of GC metastasis and infiltration. Three recent studies on expression of NEDD9 in GC patients also showed similar results. ${ }^{9,33,38}$ Collectively, these results suggest an important role of NEDD9 in the progression of GC.

In fact, elevated expression of NEDD9 has been linked to the progression of many tumors. For instance, in lung adenocarcinoma, the overexpression of NEDD9 protein is

Table 8 NEDD9 protein expression in gastric carcinoma tissue and its association with clinical biology characteristics

\begin{tabular}{|c|c|c|c|c|}
\hline $\begin{array}{l}\text { Clinicopathological } \\
\text { factors }\end{array}$ & $\mathbf{n}$ & $\begin{array}{l}\text { NEDD9 mRNA } \\
\text { expression level }\end{array}$ & $t$ & $P$-value \\
\hline Age (years) & & & 1.278 & 0.211 \\
\hline$<60$ & 17 & $0.820 \pm 0.206$ & & \\
\hline$\geq 60$ & 23 & $0.894 \pm 0.125$ & & \\
\hline Sex & & & 0.778 & 0.443 \\
\hline Male & 29 & $0.826 \pm 0.200$ & & \\
\hline Female & II & $0.877 \pm 0.153$ & & \\
\hline Tumor size $(\mathrm{cm})$ & & & 1.169 & 0.251 \\
\hline$<5$ & 25 & $0.821 \pm 0.215$ & & \\
\hline$\geq 5$ & 15 & $0.890 \pm 0.123$ & & \\
\hline Depth of invasion & & & 6.280 & $<0.001$ \\
\hline TI-2 & 18 & $0.647 \pm 0.143$ & & \\
\hline T3-4 & 22 & $0.932 \pm 0.101$ & & \\
\hline $\begin{array}{l}\text { Tumor differentiation } \\
\text { grade }\end{array}$ & & & I. 148 & 0.260 \\
\hline I-II & 26 & $0.838 \pm 0.171$ & & \\
\hline III & 14 & $0.906 \pm 0.153$ & & \\
\hline $\begin{array}{l}\text { Number of lymph } \\
\text { node metastases }\end{array}$ & & & 5.342 & $<0.001$ \\
\hline$<3$ & 17 & $0.691 \pm 0.158$ & & \\
\hline$\geq 3$ & 23 & $0.937 \pm 0.103$ & & \\
\hline
\end{tabular}


significantly correlated with staging and differentiation grade and tumor size in lung adenocarcinoma, which demonstrated a poor prognosis. ${ }^{28} \mathrm{~A}$ series of functional, biochemical, and clinical studies have established NEDD9 as a bona fide melanoma metastasis gene. NEDD9 enhanced invasion in vitro and metastasis in vivo of both normal and transformed melanocytes, functionally interacted with focal adhesion kinase and modulated focal contact formation, and exhibited frequent robust overexpression in human metastatic melanoma relative to primary melanoma. ${ }^{25}$ For breast cancers, high NEDD9 expression levels were associated with aggressive breast cancers, including triple-negative breast cancer and ERBB2-overexpressing subtypes. ${ }^{39}$ Therefore, our findings are consistent with earlier reports that elevated expression of NEDD9 has been implicated as a metastasis promoter with poor progression and prognosis in a variety of tumor types.

\section{Conclusion}

The current study indicates that NEDD9 is elevated in GC tissues in terms of both protein and mRNA levels, which were correlated with the depth of infiltration and tumor lymph node metastasis. Based on the findings, the expression of NEDD9 in GC will contribute to the identification of patients at high risk for tumor invasion and metastasis. However, the exact mechanism of NEDD9 overexpression in GC may involve a multitude of epigenetic pathways and needs to be further elucidated. Hopefully, NEDD9 may prove to be a novel molecular biomarker and promising therapeutic target for GC.

\section{Acknowledgment}

Key scientific research project of Henan Province: NEDD9 expression in gastric cancer tissue and the study on stomach cancer-NEDD9 of NEDD9-siRNA. Item number: 132102310391.

\section{Disclosure}

The authors report no conflicts of interest in this work.

\section{References}

1. Bi J, Lau SH, Lv ZL, et al. Overexpression of YKL-40 is an independent prognostic marker in gastric cancer. Hum Pathol. 2009;40(12):1790-1797.

2. Yu G, Wang J, Chen Y, et al. Overexpression of phosphorylated mammalian target of rapamycin predicts lymph node metastasis and prognosis of chinese patients with gastric cancer. Clin Cancer Res. 2009;15(5):1821-1829.

3. Zhao ZS, Wang YY, Chu YQ, Ye ZY, Tao HQ. SPARC is associated with gastric cancer progression and poor survival of patients. Clin Cancer Res. 2010;16(1):260-268.

4. Rajdev L. Treatment options for surgically resectable gastric cancer. Curr Treat Options Oncol. 2010;11(1-2):14-23.
5. Kovoor PA, Hwang J. Treatment of resectable gastric cancer: current standards of care. Expert Rev Anticancer Ther. 2009;9(1):135-142.

6. Tsugane S, Sasazuki S. Diet and the risk of gastric cancer: review of epidemiological evidence. Gastric Cancer. 2007;10(2):75-83.

7. Jemal A, Siegel R, Ward E, et al. Cancer statistics, 2008. CA Cancer J Clin. 2008;58(2):71-96.

8. Hsu NY, Chow KC, Chen WJ, Lin CC, Chou FF, Chen CL. Expression of nm23 in the primary tumor and the metastatic regional lymph nodes of patients with gastric cardiac cancer. Clin Cancer Res. 1999;5(7): $1752-1757$.

9. Zhang Q, Wang H, Ma Y, et al. Overexpression of Nedd9 is a prognostic marker of human gastric cancer. Med Oncol. 2014;31(7):33.

10. Sakai R, Iwamatsu A, Hirano N, et al. A novel signaling molecule, p130, forms stable complexes in vivo with v-Crk and v-Src in a tyrosine phosphorylation-dependent manner. EMBO J. 1994;13(16):3748-3756.

11. Law SF, Estojak J, Wang B, Mysliwiec T, Kruh G, Golemis EA. Human Enhancer of Filamentation 1 (HEF1), a novel p130Cas-like docking protein, associates with FAK, and induces pseudohyphal growth in yeast. Mol Cell Biol. 1996;16(7):3327-3337.

12. Ishino M, Ohba T, Sasaki H, Sasaki T. Molecular cloning of a cDNA encoding a phosphoprotein, Efs, which contains a Src homology 3 domain and associates with Fyn. Oncogene. 1995;11(11):2331-2338.

13. Singh MK, Dadke D, Nicolas E, et al. A novel Cas family member, HEPL, regulates FAK and cell spreading. Mol Biol Cell. 2008;19(4): $1627-1636$.

14. Tikhmyanova N, Little JL, Golemis EA. CAS proteins in normal and pathological cell growth control. Cell Mol Life Sci. 2010; 67(7):1025-1048.

15. Brábek J, Constancio SS, Siesser PF, Shin NY, Pozzi A, Hanks SK. Crk-associated substrate tyrosine phosphorylation sites are critical for invasion and metastasis of SRC-transformed cells. Mol Cancer Res. 2005;3(6):307-315.

16. Cabodi S, Tinnirello A, Di Stefano P, et al. p130Cas as a new regulator of mammary epithelial cell proliferation, survival, and HER2-neu oncogene-dependent breast tumorigenesis. Cancer Res. 2006;66(9): $4672-4680$.

17. Brinkman A, van der Flier S, Kok EM, Dorssers LC. BCAR1, a human homologue of the adapter protein p130Cas, and antiestrogen resistance in breast cancer cells. J Natl Cancer Inst. 2000;92(2):112-120.

18. van der Flier S, Brinkman A, Look MP, et al. Bcar1/p130Cas protein and primary breast cancer: prognosis and response to tamoxifen treatment. J Natl Cancer Inst. 2000;92(2):120-127.

19. Bargon SD, Gunning PW, O'Neill GM. The Cas family docking protein, HEF1, promotes the formation of neurite-like membrane extensions. Biochim Biophys Acta. 2005;1746(2):143-154.

20. Sasaki T, Iwata S, Okano HJ, et al. Nedd9 protein, a Cas-L homologue, is upregulated after transient global ischemia in rats: possible involvement of Nedd9 in the differentiation of neurons after ischemia. Stroke. 2005;36(11):2457-2462.

21. Wang Y, Bi L, Wang H, et al. NEDD9 rs760678 polymorphism and the risk of Alzheimer's disease: a meta-analysis. Neurosci Lett. 2012; 527(2):121-125.

22. Izumchenko E, Singh MK, Plotnikova OV, et al. NEDD9 promotes oncogenic signaling in mammary tumor development. Cancer Res. 2009;69(18):7198-7206.

23. Kong C, Wang C, Wang L, et al. NEDD9 is a positive regulator of epithelial-mesenchymal transition and promotes invasion in aggressive breast cancer. PLoS One. 2011;6(7):e22666.

24. Tikhmyanova N, Golemis EA. NEDD9 and BCAR1 negatively regulate E-cadherin membrane localization, and promote E-cadherin degradation. PLoS One. 2011;6(7):e22102.

25. Kim M, Gans JD, Nogueira C, et al. Comparative oncogenomics identifies NEDD9 as a melanoma metastasis gene. Cell. 2006;125(7): 1269-1281.

26. Natarajan M, Stewart JE, Golemis EA, et al. HEF1 is a necessary and specific downstream effector of FAK that promotes the migration of glioblastoma cells. Oncogene. 2006;25(12):1721-1732. 
27. Lucas JT Jr, Salimath BP, Slomiany MG, Rosenzweig SA. Regulation of invasive behavior by vascular endothelial growth factor is HEF1dependent. Oncogene. 2010;29(31):4449-4459.

28. Chang JX, Gao F, Zhao GQ, Zhang GJ. Expression and clinical significance of NEDD9 in lung tissues. Med Oncol. 2012;29(4):2654-2660.

29. Budhu A, Forgues M, Ye QH, et al. Prediction of venous metastases, recurrence, and prognosis in hepatocellular carcinoma based on a unique immune response signature of the liver microenvironment. Cancer Cell. 2006;10(2):99-111.

30. Sima N, Cheng X, Ye F, Ma D, Xie X, Lü W. The overexpression of scaffolding protein NEDD9 promotes migration and invasion in cervical cancer via tyrosine phosphorylated FAK and SRC. PLoS One. 2013;8(9):e74594.

31. Ye X, Wang L, Shang B, Wang Z, Wei W. NEDD4: a promising target for cancer therapy. Curr Cancer Drug Targets. 2014;14(6):549-556.

32. Abidi N, Xirodimas D. Regulation of cancer related pathways by NEDDylation and the use of NEDD8 inhibitors in the clinic. Endocr Relat Cancer. 2014.

33. Liu Y, Wang D, Zhao KL, et al. NEDD9 overexpression correlates with poor prognosis in gastric cancer. Tumour Biol. 2014;35(7): 6351-6356.
34. Li Y, Tian B, Yang J, et al. Stepwise metastatic human hepatocellular carcinoma cell model system with multiple metastatic potentials established through consecutive in vivo selection and studies on metastatic characteristics. J Cancer Res Clin Oncol. 2004;130(8):460-468.

35. Jacinto E, Loewith R, Schmidt A, et al. Mammalian TOR complex 2 controls the actin cytoskeleton and is rapamycin insensitive. Nat Cell Biol. 2004;6(11):1122-1128.

36. Shitara K, Mizota A, Yatabe Y, et al. Lapatinib plus trastuzumab for a patient with heavily pre-treated gastric cancer that progressed after trastuzumab. Jpn J Clin Oncol. 2011;41(5):663-665.

37. Chua TC, Merrett ND. Clinicopathologic factors associated with HER2-positive gastric cancer and its impact on survival outcomes - a systematic review. Int J Cancer. 2012;130(12):2845-2856.

38. Shi R, Wang L, Wang T, Xu J, Wang F, Xu M. NEDD9 overexpression correlates with the progression and prognosis in gastric carcinoma. Med Oncol. 2014;31(3):852.

39. Bradbury P, Mahmassani M, Zhong J, et al. PP2A phosphatase suppresses function of the mesenchymal invasion regulator NEDD9. Biochim Biophys Acta. 2012;1823(2):290-297.
OncoTargets and Therapy

\section{Publish your work in this journal}

OncoTargets and Therapy is an international, peer-reviewed, open access journal focusing on the pathological basis of all cancers, potential targets for therapy and treatment protocols employed to improve the management of cancer patients. The journal also focuses on the impact of management programs and new therapeutic agents and protocols on

\section{Dovepress}

patient perspectives such as quality of life, adherence and satisfaction. The manuscript management system is completely online and includes a very quick and fair peer-review system, which is all easy to use. Visit http://www.dovepress.com/testimonials.php to read real quotes from published authors. 